\title{
THE INCORPORATION OF COPPER INTO CERULOPLASMIN IN VIVO: STUDIES WITH COPPER ${ }^{64}$ AND COPPER ${ }^{67 *}$
}

\author{
By IRMIN STERNLIEB, ANATOL G. MORELL, WALTER D. TUCKER, \\ MARGARET W. GREENE AND I. HERBERT SCHEINBERG \\ (From the Department of Medicine, Albert Einstein College of Medicine, and Bronx Munici- \\ pal Hospital Center, New York, N. Y., and Radioisotope Development Section, \\ Hot Laboratory Division, Brookhaven National Laboratory, Upton, N. Y.)
}

(Submitted for publication April 28, 1961 ; accepted May 29, 1961)

The fact that absence or deficiency of the plasma copper-protein, ceruloplasmin, is almost always associated with the excessive deposits of tissue copper which characterize Wilson's disease has suggested that ceruloplasmin regulates copper absorption or excretion (1). Based on the in vitro demonstration of reversible dissociation of copper from ceruloplasmin, a hypothesis was proposed of how such regulation could be effected (2). This stated that if reversible dissociation of copper from ceruloplasmin occurred in the intestinal wall in vivo, a concentration of copper ions would result which could oppose the net transfer of copper ions from the intestinal lumen into the blood. The three experiments reported in this paper were designed to determine whether exchange of ceruloplasmin copper for ionic copper, which is equivalent to reversible dissociation of ceruloplasmin copper, takes place in vivo.

In the first experiment, exchange of ceruloplasmin copper was looked for in patients with Wilson's disease in whom virtually no synthesis of the protein was occurring. The interpretation of this experiment required knowledge of whether the catabolism of ceruloplasmin was detectably different in a normal individual from its catabolism in patients with Wilson's disease. A comparison of the half-life of ceruloplasmin, as one measure of its catabolism, was made in these two types of individuals in the second experiment. In the third experiment, the incorporation of ionic copper into ceruloplasmin was studied in an individual with normal copper metabolism in such a

* Presented in part at the Eastern Section Meeting of the American Federation for Clinical Research, January 6, 1961, Bethesda, Md. This work was supported in part by grants from the National Institute of Arthritis and Metabolic Diseases of the United States Public Health Service (A-1059), and the Life Insurance Medical Research Fund (G-60-54). way that incorporation occurring during synthesis of ceruloplasmin could be differentiated from that resulting from copper exchange.

All of our results were compatible with the conclusions that copper entered the ceruloplasmin molecule only at the time of synthesis, and that exchange of ceruloplasmin copper with ionic copper did not occur in vivo. Since it was a corollary of these conclusions that a given copper atom was a label which remained on a ceruloplasmin molecule throughout its life span, we were able to calculate the rate of turnover of ceruloplasmin, and its copper, in an individual with normal copper metabolism.

\section{EXPERIMENTAL}

\section{Materials and methods}

Ceruloplasmin. Two solutions ( $\mathrm{CH}-157$ and $\mathrm{CH}-240)$, which contained 2.9 and $2.1 \mathrm{~g}$ of purified human ceruloplasmin per $100 \mathrm{ml}$, respectively, were obtained from the Ortho Research Foundation, Raritan, N. J. ${ }^{1}$ Both preparations were sterile, nontoxic, nonpyrogenic and their intravenous administration to human beings produced no ill effects.

Copper ${ }^{\text {s4 }}$. Sterile solutions of cupric ${ }^{\text {s4 }}$ acetate were obtained from Abbott Laboratories, Oak Ridge, Tenn. The half-life of this isotope is 12.8 hours (3).

Copper ${ }^{67}$. Copper ${ }^{67}$ was produced in the 60 -inch cyclotron of the Brookhaven National Laboratory by the following $(\alpha, p)$ reaction: $\mathrm{Ni}^{64}+\mathrm{He}^{4} \rightarrow \mathrm{Cu}^{67}+\mathrm{H}^{1}$. Since there is only 1 per cent of $\mathrm{Ni}^{\mathrm{es}}$ in naturally occurring nickel, material enriched to 96 per cent $\mathrm{Ni}^{\text {es }}$ was obtained from the Isotope Division of the Oak Ridge National

1 Through the cooperation of Sam T. Gibson, Director, American National Red Cross Blood Program, and James A. McComb, John M. Newell and Lewis H. Larsen of the Biologic Laboratories, Department of Public Health of the Commonwealth of Massachusetts, we obtained Cohn fraction IV-1 from human plasma. Ceruloplasmin was prepared from fraction IV-1 under the direction of H. O. Singher of the Ortho Research Foundation, Raritan, N. J. 
TABLE I

Labeling of ceruloplasmin with copper ${ }^{67}$ by Method $A$

\begin{tabular}{|c|c|c|c|c|c|c|c|c|}
\hline Expt. & Subj. & Cer & s) & $\begin{array}{l}0.85 \% \\
\mathrm{NaCl}\end{array}$ & $\begin{array}{l}\text { Ascorbic } \\
\text { acid }\end{array}$ & $\underset{\text { nitrate* }}{\mathrm{Cu}^{67}}$ & $\mathrm{Cu}^{67}$ & Final $\mathrm{pH}$ \\
\hline $\begin{array}{l}\text { I } \\
\text { I }\end{array}$ & $\begin{array}{l}\text { G.G. } \\
\text { D.S. }\end{array}$ & $\begin{array}{c}m l \\
63.0 \\
63.0\end{array}$ & $\begin{array}{c}g \\
1.32 \\
1.32\end{array}$ & $\begin{array}{c}m l \\
240 \\
340\end{array}$ & $\begin{array}{c}m g \\
785 \\
785\end{array}$ & $\begin{array}{c}m l \\
2.3 \\
2.0\end{array}$ & $\begin{array}{l}\mu g \\
71 \\
62\end{array}$ & $\begin{array}{l}6.18 \\
6.45\end{array}$ \\
\hline
\end{tabular}

* This solution contained $31 \mu \mathrm{g}$ copper $/ \mathrm{ml}$ with a specific activity of $1.21 \mu \mathrm{c} / \mu \mathrm{g}$.

Laboratory and used as the target. Although enriched nickel $^{\text {b4 }}$ was relatively expensive, it could be recovered with a yield of about 98 per cent and reused.

To prepare approximately 1 to $2 \mathrm{mc}$ of copper ${ }^{67}, 60 \mathrm{mg}$ of the nickel ${ }^{\text {b4 }}$ was electroplated as metal onto gold foil that had been silver-soldered to a copper target holder. (The area covered by the nickel was roughly $1 / 4 \times 3 / 8$ inch. It varied in thickness from 0.007 to 0.010 inch, which was sufficient to absorb the entire alpha beam.) The target assembly was mounted on a watercooled probe that was inserted into the vacuum chamber of the cyclotron, and the nickel ${ }^{\text {et }}$ target was bombarded by the internal beam of $40 \mathrm{Mev}$ alpha particles. At the current of 50 to $60 \mu \mathrm{a}$ which resulted, bombardments of 10 to 12 hours were required. For example, $1.4 \mathrm{mc}$ was produced in a $500 \mu \mathrm{a}$-hour bombardment, which corresponded to a thick-target yield of $2.8 \mu \mathrm{c}$ per $\mu \mathrm{a}$-hour.

The target was removed from the cyclotron and the gold foil was separated from the target holder by melting the silver solder. The bombarded nickel was dissolved in a few drops of nitric acid. After addition of $0.5 \mathrm{mg}$ of copper carrier, hold-back carriers of indium, cadmium and cobalt, and 2 or 3 drops of concentrated sulfuric acid, the copper was electroplated at $80^{\circ} \mathrm{C}$ for 30 minutes onto a platinum electrode. The copper was dissolved from the platinum with nitric acid and was used without sterilization. The processing yield was estimated to be at least 95 per cent. The only radiocontaminant present in significant amount was copper" which constituted initially about 7 per cent of the total radioactivity.

Nitric acid was removed from the solution which remained after the electroplating of copper by evaporation to fumes of sulfur trioxide. The residue was diluted with water, made alkaline with concentrated ammonia, and the nickel ${ }^{\text {st }}$ was recovered by electroplating.

The half-life of copper ${ }^{67}$ was determined to be $61.8 \pm 0.8$ hours. To our knowledge the experiments reported in this paper represent the first use of this isotope in biological research.

\section{Radioactive labeling of ceruloplasmin copper}

1. Method $A$. To a solution of purified ceruloplasmin in physiological saline, ascorbic acid and then copperer nitrate were added. After standing at room temperature for 1.5 hours, approximately 35 per cent of the copper ${ }^{\text {er }}$ was found to have been incorporated into the ceruloplasmin of each solution by exchange. The amounts of material used for the two preparations are given in Table I.

2. Method B. Two male volunteers, aged 50 and 64 , received $1.0 \mathrm{mg}$ of ethinyl estradiol (Estinyl) daily for 5 days in order to elevate their plasma concentrations of ceruloplasmin $(4,5)$. By intravenous injection they were then given, respectively, 3.45 and $4.77 \mathrm{mg}$ of $\mathrm{Cu}^{87}$, with a specific activity of $105 \mu \mathrm{c}$ per $\mathrm{mg}$, as cupric ${ }^{67} \mathrm{ni}-$ trate. $^{2}$ Forty hours later a phlebotomy was performed on each volunteer yielding, in a total of $450 \mathrm{ml}$ of plasma, $286 \mathrm{mg}$ of labeled ceruloplasmin. This contained $88 \mu \mathrm{g}$ of ceruloplasmin-bound $\mathrm{Cu}^{67}$, and only $1.3 \mu \mathrm{g}$ of nonceruloplasmin $\mathrm{Cu}^{\text {or. }}$. Thus, this material was of much greater value in studying ceruloplasmin metabolism in a control subject than ceruloplasmin labeled by Method A which always contained a large amount of nonceruloplasmin copper $^{67}$. Although the incidental administration of the latter was unimportant in the experiment in the 2 patients with Wilson's disease, who cannot synthesize ceruloplasmin, nonceruloplasmin copper would have entered newly synthesized ceruloplasmin in control subjects in vivo and made Experiment II impossible.

Quantitative determination of ceruloplasmin. Ceruloplasmin concentrations in serum were measured by determining the oxidase activity of serum toward paraphenylenediamine (2).

Quantitative determination of radioactive copper ${ }^{\text {s4 }}$ and copper. Four-ml aliquots of serum, or smaller aliquots brought to $4 \mathrm{ml}$ by addition of normal saline, were counted in a Nuclear-Chicago DS5-5 well-type scintillation counter by means of a $161 \mathrm{~A}$ scaler. Discrimination between the $0.184 \mathrm{Mev}$ gamma rays of $\mathrm{Cu}^{\text {or }}$ (3) and the $0.51 \mathrm{Mev}$ annihilation gamma rays (6) of $\mathrm{Cu}^{\text {at }}$ was effected by inclusion of a Nuclear-Chicago 1810 radiation analyzer in the circuit. Correction for background and physical decay yielded net corrected counts per minute per milliliter of serum due to each isotope.

Separation of nonceruloplasmin copper. In order to determine the proportion of the radioisotopic copper in serum bound to ceruloplasmin in Experiments I and III, the nonceruloplasmin copper in the serum was made to react with sodium diethyldithiocarbamate (DTC) and

2 In order to keep the copper in solution, each dose of $\mathrm{Cu}^{67}$ was dissolved in a mixture of $60 \mathrm{ml}$ Amigen (5 per cent enzymic casein hydrolysate and 5 per cent dextrose, in water) and $0.5 \mathrm{ml}$ of 7.5 per cent sodium bicarbonate. The solutions were clear, blue, and had a $\mathrm{pH}$ of 5.2. Neither produced any untoward reaction when infused. 

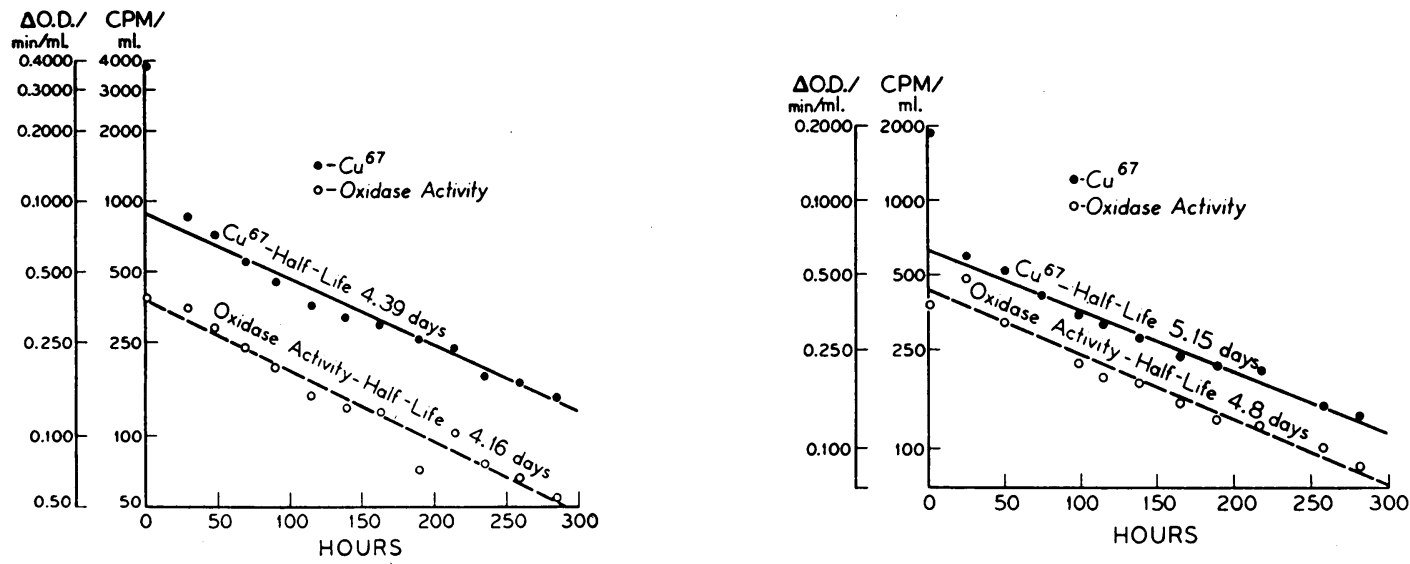

Fig. 1. HALF-LIFE OF COPPER ${ }^{67}$-LABELED CERULOPLASMIN OBTAINED FROM THE RATES OF DiSAPPEARANCE OF OXIDASE ACTIVITY AND RADIOACTIVITY OF SERUM IN TWO ACERULOPLASMINEMIC PATIENTS WITH WILSON'S DISeASe, G.G. (LEFT) AND D.S. (RIGHT).

the colloidal $\mathrm{Cu}$-DTC complex was adsorbed on a column of activated charcoal, as follows. After dilution of $3 \mathrm{ml}$ of serum with an equal volume of normal saline, $0.6 \mathrm{ml}$ of a 0.1 per cent solution of DTC in saline was added. The mixture was passed through a column of $100 \mathrm{mg}$ of activated charcoal (Norit-A). The $4 \mathrm{ml}$ of effluent which followed the $1.5 \mathrm{ml}$ fore-run had the same concentration of ceruloplasmin as that contained in the $6.6 \mathrm{ml}$ of solution passed over the column, and contained neither free copper nor free DTC.

\section{RESULTS}

Experiment I. We infused $1.32 \mathrm{~g}$ of ceruloplasmin, labeled by Method A with copper ${ }^{67}$, into each of two patients with Wilson's disease without serum ceruloplasmin. There were no untoward effects on pulse, respiration, blood pressure, or venous clotting and prothrombin times. Serial measurements of the serum concentration of the protein were obtained both by 1 ) determining the oxidase activity of the serum toward paraphenylenediamine and 2) counting the radioactivity of the serum. The latter was approximately equivalent to determining copper ${ }^{67}$ in ceruloplasmin since, beyond 24 hours after infusion, less than 10 per cent of copper $^{67}$ in serum was nonceruloplasmin copper ${ }^{67}$. The results are given in Figure 1. The values for the half-life of ceruloplasmin given in the figure and in Table II were calculated independently from the results of both the enzymatic and radioactive measurements by the method of least squares. The volumes of distribution of the infused protein (Table II) were obtained by dividing the amounts administered by the serum concentration of ceruloplasmin at zero time determined by extrapolation.

TABLE II

Volumes of distribution, half-lives and daily turnover rate of ceruloplasmin and ceruloplasmin copper

\begin{tabular}{|c|c|c|c|c|c|c|c|}
\hline \multirow{2}{*}{$\frac{\text { Expt. }}{\text { I }}$} & \multirow{2}{*}{$\frac{\text { Subj. }}{\begin{array}{c}\text { G.G. (Wilson's } \\
\text { disease) }\end{array}}$} & \multirow{2}{*}{$\begin{array}{c}\begin{array}{c}\text { Volume } \\
\text { of distri- } \\
\text { bution }\end{array} \\
L \\
3.77\end{array}$} & \multirow{2}{*}{$\begin{array}{c}\begin{array}{c}\text { Oxidase } \\
\text { activity } \\
\text { half-life }\end{array} \\
\text { days } \\
4.16\end{array}$} & \multirow{2}{*}{$\begin{array}{c}\begin{array}{r}\text { Radio- } \\
\text { activity } \\
\text { half-life }\end{array} \\
\text { days } \\
4.39\end{array}$} & \multicolumn{2}{|c|}{$\begin{array}{l}\text { Daily turnover rate of } \\
\text { ceruloplasmin* }\end{array}$} & \multirow{2}{*}{$\begin{array}{c}\begin{array}{c}\text { Daily } \\
\text { turnove } \\
\text { rate of } \\
\text { cerulo- } \\
\text { plasmin } \\
\text { copper }\end{array} \\
\begin{array}{c}m g \\
0.704\end{array}\end{array}$} \\
\hline & & & & & $\begin{array}{c}\% \\
15.7\end{array}$ & $\begin{array}{c}m g \\
207.2 \dagger\end{array}$ & \\
\hline I & $\begin{array}{l}\text { D.S. (Wilson's } \\
\text { disease) }\end{array}$ & 3.41 & 4.80 & 5.15 & 13.4 & $176.9 \dagger$ & 0.601 \\
\hline II & J.M. (control) & 3.97 & & 5.40 & 12.9 & 141.9 & 0.483 \\
\hline
\end{tabular}

* Calculated from radioactivity measurements.

$\dagger$ Immediately after infusion. 
Experiment II. Into a normal male volunteer, aged $22,450 \mathrm{ml}$ of plasma containing $286 \mathrm{mg}$ of copper $^{67}$-labeled ceruloplasmin (Method B) was infused. The concentration of the copper ${ }^{67}$-labeled ceruloplasmin was measured daily by determining the radioactivity of whole serum, and these results were used to calculate the half-life of ceruloplasmin and its volume of distribution (Figure 2 and Table II). In contrast to the previous experiment, we could not also calculate these values from measurements of oxidase activity, since the oxidase activity of the infused, labeled ceruloplasmin could not be distinguished from that of the subject's own ceruloplasmin which was continually being synthesized.

Experiment III. A 39 year old female with Huntington's chorea and no detectable abnormality of copper metabolism was given $2 \mathrm{mg}$ of copper ${ }^{64}$ orally, as cupric ${ }^{64}$ acetate, on three different and widely separated occasions. 1) The first dose was administered when the patient's ceruloplasmin concentration was at a normal value, $26.7 \mathrm{mg}$ per $100 \mathrm{ml}$ of serum. 2) The second was given 5 days after she had received, for 15 days, $1 \mathrm{mg}$ ethinyl estradiol daily. The estrogen served to increase the rate of synthesis of ceruloplasmin and to raise

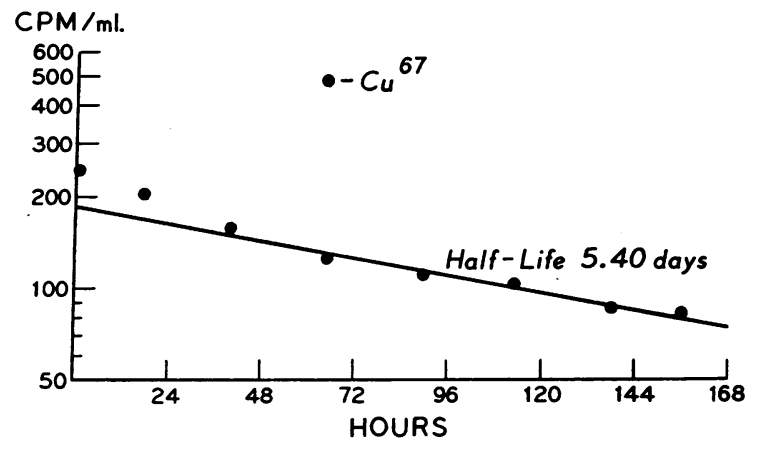

Fig. 2. HALF-LIFE OF COPPER ${ }^{67}$-LABELED CERULOPLASMIN OBTAINED FROM THE RATE OF DISAPPEARANCE OF THE RADIOACTIVITY OF SERUM IN A CONTROL SUBJECT (J.M.).

its serum concentration from 29.2 to $51.9 \mathrm{mg}$ per $100 \mathrm{ml}(4,5) .3)$ The third administration of copper ${ }^{64}$ occurred 1 day after she had received an infusion of $1.39 \mathrm{~g}$ of purified human ceruloplasmin (CH-157). The infusion did not, of course, increase the rate of synthesis of ceruloplasmin, but did raise its serum concentration from 25.5 to $74.1 \mathrm{mg}$ per $100 \mathrm{ml}$. The concentration of serum copper $^{64}$ and its proportion in ceruloplasmin were measured at intervals (Figure 3 ) after each dose of copper ${ }^{64}$.

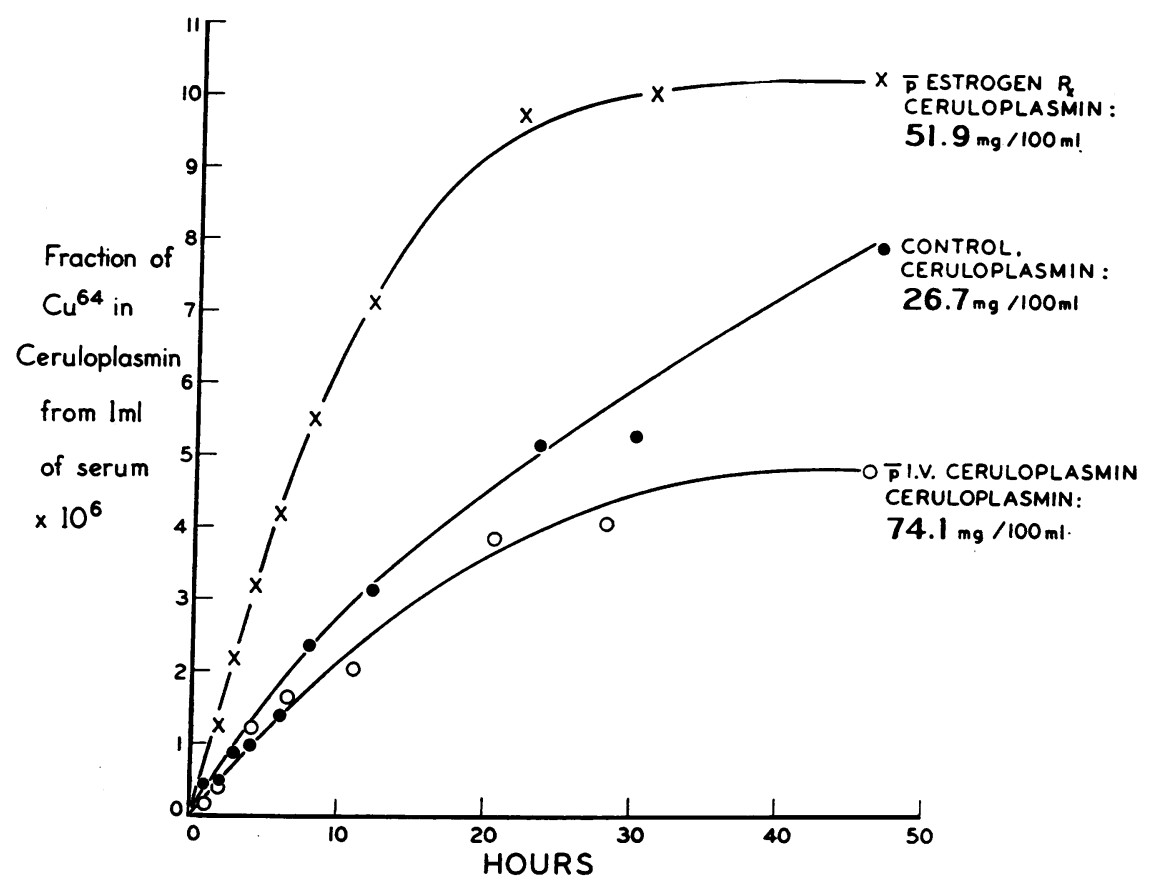

Fig. 3. INCORPORATION OF COPPER ${ }^{\text {et }}$ INTO CERULOPLASMIN IN A CONTROL SUBJECT (P.N.) UNDER THREE DIFFERENT EXPERIMENTAL CONDITIONS. 


\section{DISCUSSION}

Experiment I indicated that in vivo exchange of ceruloplasmin copper did not occur in either of two patients with Wilson's disease. Entire ceruloplasmin molecules disappeared at a rate not significantly different from that at which ceruloplasmin-copper ${ }^{67}$ disappeared from the plasma. $^{3}$ The latter rate should have exceeded the former if exchange had occured between ceruloplasmincopper $^{6 \tau}$ and the "cold" copper of the body.

It is, of course, conceivable that the ceruloplasmin which we infused could have been altered during fractionation, in which case the absence of exchange might only imply that this ceruloplasmin had lost its physiological integrity. Yet by every other property which was measured the ceruloplasmin seemed undenatured: its labile blue color (7), its tight copper-binding, its electrophoretic mobility (7), its lack of antigenicity in human beings, ${ }^{4}$ and its oxidase activity (10) were virtually identical with these properties of ceruloplasmin in whole plasma or serum. Nevertheless, this experiment did not provide evidence that exchange might not have occurred in normal individuals, since the metabolism of ceruloplasmin may differ in the two groups. Consequently, we performed Experiment II in order to compare the half-life of ceruloplasmin, as measured in these patients with Wilson's disease, with the half-life in a normal individual. The half-life of $\operatorname{copper}^{67}$ labeled ceruloplasmin did not differ significantly in a simultaneous test of the values determined in the two patients and in the control subject. ${ }^{5} \mathrm{By}$ this criterion, therefore, ceruloplasmin did not

\footnotetext{
${ }^{3}$ For each patient the differences between the $\log$ (oxidase activity) and $\log$ (radioactivity) at each sampling time were plotted against time, the slope of the resulting line being designated as $b$. Then $|b-0| / \mathrm{SE}_{b}=|t|$ was calculated, for the indicated degrees of freedom, and found to be $t_{10}=0.785$ for G.G. and $t_{s}=1.2104$ for D.S. In both cases a $|t|$ as great, or greater, might have been found, by chance alone, more than 50 per cent of the time.

4 Insofar as this is indicated by the constancy of the determined half-life and the lack of any clinical reaction incident to repeated infusions of purified ceruloplasmin in G.G. and D.S. over the past 4 years $(8,9)$.

5 An analysis of covariance (11) was used to test the hypothesis that these three values for the half-life did not differ significantly. An $F$ of 3.129 , with 2 and 23 degrees of freedom, was obtained which could occur by chance alone more than 5 per cent of the time.
}

seem to be metabolized at a different rate in the patients than in the control subject.

Rather similar values for the half-life of ceruloplasmin in patients with Wilson's disease and in control individuals, whether determined in studies with purified ceruloplasmin or with whole blood, have also been found previously. Thus we have reported the half-life of ceruloplasmin to be 3.2 to 4.7 days after the infusion of whole blood (8), and 5.6 to 7.2 days after administration of unlabeled purified human ceruloplasmin (9), in patients with Wilson's disease. Gitlin and Hughes [quoted in (12)], using I ${ }^{131}$-labeled purified human ceruloplasmin, found half-lives of 5 to 7 days in five chronically ill subjects without Wilson's disease. $^{6}$ Half-lives of fibrinogen $(13,14)$, the $\gamma$-globulins (12), and albumin (15) have also been compared in subjects with hereditary deficiency of the protein and in control subjects. The results do not consistently indicate either similar or different half-lives for these proteins in the two kinds of individuals.

Finally, Experiment III confirmed that in vivo exchange did not occur in an individual without an apparent abnormality of copper metabolism. When P.N.'s rate of synthesis of ceruloplasmin was approximately doubled by the administration of estrogen (Study B), about twice as much copper $^{64}$ was incorporated into the protein as in control Study A. However, when an even higher serum concentration of ceruloplasmin was achieved passively, that is, by infusion (Study C), the incorporation of copper ${ }^{64}$ into ceruloplasmin was essentially the same as that which occurred in Study A, indicating that exchange was not occurring.

Our inability to demonstrate exchange of ceru-

6 Differences in the values of half-lives may reflect the manner in which they are calculated. Thus, our values in Experiments I and II are calculated from all of the points determined after the first 24 hours. If, however, we assume that 3 days is required for equilibration of infused ceruloplasmin between plasma and extravascular compartments, the results are somewhat different. For example, the latter assumption yields $4.80,5.97$ and 6.36 days for the three values which were given in Table II as $4.39,5.15$ and 5.40 days, respectively. For the purposes of the present paper, the important point is that all values of a half-life which are to be compared should be calculated from measurements made after the same period of equilibration. 
loplasmin copper for ionic copper in any of these experiments is strong evidence that reversible dissociation of copper from ceruloplasmin does not occur in vivo. Since the hypothesis which two of us have advanced [I.H.S. and A.G.M (2)] and which was briefly outlined above, was predicated on the assumption that such dissociation does occur, this hypothesis is not likely to be true.

If, however, a copper atom labels a ceruloplasmin molecule throughout its lifetime we can use our results to calculate the volume of distribution and turnover of ceruloplasmin. The values for volume of distribution are remarkably similar in all three subjects (Table II). The percentage turnover of ceruloplasmin and of ceruloplasmin copper was calculated in all three subjects from the standard equation (16) (Table II), and the fact that the copper content of the protein is 0.34 per cent (7). The value of $142 \mathrm{mg}$ for the daily turnover of ceruloplasmin in the control subject, J.M., corresponds to $0.5 \mathrm{mg}$ of copper incorporated into ceruloplasmin daily. This must be close to the amount of copper which is absorbed from the 2 to $5 \mathrm{mg}$ of copper ingested in the diet (17). Thus it seems that much of the absorbed dietary copper in a normal individual may ultimately be bound to a ceruloplasmin molecule of 151,000 mol wt. Such bound copper should be confined largely to the vascular compartment, and the volume of distribution of $3.97 \mathrm{~L}$ found in J.M. indicates that it is.

Despite the apparent congruence of the amount of copper absorbed and that which is used daily for the synthesis of ceruloplasmin, our results do not greatly clarify the physiological role of ceruloplasmin and its relationship to Wilson's disease. They yield no information, and little additional data are available, about: 1) the period which elapses between absorption of dietary copper and its quantitative incorporation into ceruloplasmin; 2) the fate of copper during this time; and 3) whether, and where, ceruloplasmin copper is excreted. Nor do they elucidate the significance of patients with Wilson's disease who have normal serum concentrations of ceruloplasmin, or of healthy heterozygous carriers of the disease who have abnormally low serum concentrations of this protein $(1,18)$. Furthermore, the physiological significance of the in vitro demonstrations of the reversible dissociation of ceruloplasmin copper $(2$,
19), of the oxidase activity of ceruloplasmin (1) and of its heterogeneity (20) is also obscure. These questions require further investigation.

\section{SUMMARY}

1. The hypothesis that ceruloplasmin exchanges its copper for ionic copper in vivo was tested, by means of ceruloplasmin labeled with copper ${ }^{64}$ and copper $^{67}$, in two patients with Wilson's disease and in two control subjects.

2. No indication of exchange was found in any of three different experiments. It appears that copper is incorporated into the ceruloplasmin molecule in vivo only at the time of synthesis of the protein and not through exchange.

3. A corollary of these results is that copper is a lifelong label of a ceruloplasmin molecule so that radioactive copper may be used for the determination of the turnover of ceruloplasmin and ceruloplasmin copper.

4. The amount of copper incorporated daily into ceruloplasmin in a control subject corresponds closely to the amount of copper absorbed from the dietary intake.

\section{ACKNOWLEDGMENTS}

We are indebted to Dr. George C. Cotzias, Dr. Quentin B. Deming, Mr. Daniel Horowitz and Mrs. Georgine J. Chulstrom for their cooperation; to Drs. D. A. Brancazio, L. Kresch, H. Lubowitz, R. M. Rothman and W. Rosenbaum, and Mrs. B. Schorr, R.N. and Miss L. King, R.N. for their assistance in carrying out the metabolic studies; to Mrs. Shirley de Bobes-Sternberg, of the Division of Biostatistics, Columbia University Faculty of Medicine, for evaluating our results statistically; and to Miss Josephine Brosseau for performing all the determinations of oxidase activity.

\section{REFERENCES}

1. Scheinberg, I. H., and Sternlieb, I. Copper metabolism. Pharmacol. Rev. 1960, 12, 355.

2. Scheinberg, I. H., and Morell, A. G. Exchange of ceruloplasmin copper with ionic $\mathrm{Cu}^{\text {et }}$ with reference to Wilson's disease. J. clin. Invest. 1957, 36, 1193.

3. Way, K., King, R. W., McGinnis, C. L., and van Lieshout, R. Nuclear level schemes. $A=40-$ $A=92$. Washington, D. C., National Academy of Sciences, National Research Council, 1955.

4. Russ, E. M., and Raymunt, J. Influence of estrogens on total serum copper and caeruloplasmin. Proc. Soc. exp. Biol. (N. Y.) 1956, 92, 465. 
5. German, J. L., III, and Bearn, A. G. Effect of estrogens on copper metabolism in Wilson's disease. J. clin. Invest. 1961, 40, 445.

6. Quimby, E. H., Feitelberg, S., and Silver, S. in Radioactive Isotopes in Clinical Practice. Philadelphia, Lea and Febiger, 1958, chap. 6, p. 68.

7. Holmberg, C. G., and Laurell, C.-B. Investigations in serum copper II. Isolation of the copper containing protein, and a description of some of its properties. Acta chem. scand. 1948, 2, 550.

8. Scheinberg, I. H., Harris, R. S., Morell, A. G., and Dubin, D. Some aspects of the relation of ceruloplasmin to Wilson's disease. Neurology 1958, 8, suppl. 1, 44.

9. Scheinberg, I. H., and Sternlieb, I. Environmental treatment of a hereditary illness: Wilson's disease. Ann. intern Med. 1960, 53, 1151.

10. Holmberg, C. G., and Laurell, C.-B. Oxidase reactions in human plasma caused by coeruloplasmin. Scand. J. clin. Lab. Invest. 1951, 3, 103.

11. Dixon, W. J., and Massey, F. J. in Introduction to Statistical Analysis. New York, McGraw-Hill, 1957, p. 209.

12. Gitlin, D., and Janeway, C. A. Genetic alterations in plasma proteins of man in The Plasma Proteins, F. W. Putnam, Ed. New York, Academic Press, 1960 , vol. 2 , p. 407.
13. De Vries, A., Rosenberg, T., Kochwa, S., and Boss, J. H. Precipitating antifibrinogen antibody appearing after fibrinogen infusions in a patient with congenital afibrinogenemia. Amer. J. Med. 1961, 30, 486.

14. Gitlin, D., and Borges, W. H. Studies on the metabolism of fibrinogen in two patients with congenital afibrinogenemia. Blood 1953, 8, 679.

15. Bennhold, H., and Kallee, E. Comparative studies on the half-life of $\mathrm{I}^{131}$-labeled albumins and nonradioactive human serum albumin in a case of analbuminemia. J. clin. Invest. 1959, 38, 863.

16. Zilversmit, D. B. The design and analysis of isotope experiments. Amer. J. Med. 1960, 29, 832.

17. Sternlieb, I., Morell, A. G., and Scheinberg, I. H. Unpublished observations.

18. Sternlieb, I., Morell, A. G., Bauer, C. D., Combes, B., de Bobes-Sternberg, S., and Scheinberg, I. H. Detection of the heterozygous carrier of the Wilson's disease gene. J. clin. Invest. 1961, 40, 707.

19. Morell, A. G., and Scheinberg, I. H. Preparation of an apoprotein from ceruloplasmin by reversible dissociation of copper. Science 1958, 127, 588.

20. Morell, A. G., and Scheinberg, I. H. Heterogeneity of human ceruloplasmin. Science 1960, 131, 930. 